\title{
Disaster, Divine Judgment, and Original Sin: Christian Interpretations of Tropical Cyclone Winston and Climate Change in Fiji
}

\author{
John Cox, Glen Finau, \\ Romitesh Kant, Jason Titifanue, \\ and Jope Tarai
}

\begin{abstract}
$A_{s}$ the people of the Pacific feel the impact of recent superstorms, earthquakes, environmental degradation, and climate change, and as the region is represented by external actors as a place particularly vulnerable to natural disasters (eg, Keener and others 20I2), a new moral economy is emerging. Expectations of economic growth and linear development are becoming difficult to sustain in the face of the devastation of major disasters such as Tropical Cyclones Winston (February 2016) and Pam (March 2015), where the financial costs, labor, and time required to rebuild infrastructure outweigh any of the incremental gains from economic progress in recent years. Natural disasters have the most severe impacts on the poor, thereby also exacerbating existing social inequality. This vulnerable and unstable image of the Pacific sits in tension with more familiar ideas of the region as a tranquil tropical paradise.

Paradise in the Pacific is often rendered as a natural state in which "native" people live in simple harmony or "subsistence affluence" without the need for government or state institutions For example, Matti Eräsaari has noted that Fijians themselves frequently refer to village life as "Parataisi" as they celebrate the abundant provision of food and the ability to live without money or the time disciplines of waged employment (2017, 316). As Sharae Deckard has argued (2010), the paradise myth was foundational to colonial exploitation as it attributed prosperity to natural abundance, rendering the forced labor of "natives" invisible and displacing claims of Indigenous ownership of land. These narratives have
\end{abstract}

The Contemporary Pacific, Volume 30, Number 2, 380-4 I I

(C) 2018 by University of Hawai'i Press 
not only been imposed on Pacific people-not least through contemporary tourism discourses (Alexeyeff and Taylor 2016) - but have also been reappropriated by them through Indigenous Christian and postcolonial nationalist perspectives.

This article takes recent Fijian Christian interpretations of Tropical Cyclone Winston as a key site in which contested ideologies of paradise are being reworked. As the idyll of island harmony is disrupted by natural disasters, Christian traditions invoke paradise not simply as a state of innocence but as a narrative of salvation history in which paradise is lost through sin and must be restored through sacrifice and repentance. For iTaukei (Indigenous Fijians), this salvation history of paradise given, lost, and regained is an emplaced history, grounded in ideas about vanua as a sacred homeland that is central to the relationship between iTaukei and God (Presterudstuen 2016, 97; Tomlinson 20II). The vanua is a kind of paradise that acts to house and provision the chosen nation. However, this Christian nationalist interpretation sits in tension with the counterclaims of the tourism industry in which, in keeping with Deckard (2010), Fiji and its Indigenous inhabitants function merely as a backdrop for Australian leisure activities (Connell 2016). Furthermore, neither of these views of Fiji as a natural paradise account for the presence of Indo-Fijians. Based on the idea of iTaukei as a chosen people akin to Israel in the Bible, many Fijian Christians have seen Tropical Cyclone Winston as an act of divine judgment and punishment.

In the wake of Tropical Cyclone Winston, we consider how some of these issues of regional and national moral economy, disasters, and climate change are understood by Fijian Christians. Drawing on print media and (often heated) debates about the meaning of the cyclone among Fijians on selected Facebook groups, as well as participant observation of informal conversations, public events, and sermons by Glen Finau, Romitesh Kant, Jope Tarai, and Jason Titifanue, this essay analyzes how narratives of a sinful nation and paradise intersect with contemporary formulations of climate change, disaster, politics, and human agency. We suggest that accounts of who is to blame for natural disasters or climate change appear to shift as related discourses move across local, national, or global scales, and that different local, national and international actors come into view or, alternatively, are obscured by these processes. However, these narratives of blame are consistent in involving the Christian theological premise of original sin and therefore also broader imaginaries of paradise, both lost and regained. 


\section{Climate Change and Disasters in the Pacific}

Within the region and beyond, the Pacific Islands are being redefined as an area that is particularly vulnerable to natural disasters and other effects of climate change. This characterization has been intensifying over the past decade. Rises in sea level, severe cyclones, and changes in climatic conditions have meant that Pacific Islands face many threats, including coastal inundation and the submergence of low-lying islands; increased salinization of water sources; and changes in the distribution of biodiversity, potentially threatening food security and economic prosperity (Keener and others 2OI2). The warming of the earth's oceans means that cyclones are likely to become more intense in their effects and may spread to cooler areas that do not currently give rise to cyclonic activity (Pacific Climate Change Science Program 20II). Given the region's limited financial resources as well as economic structures that are vulnerable to global markets, climate change poses a formidable challenge for Pacific leaders and communities.

In diplomatic, academic, and popular discourses, the low-lying atoll states of Kiribati, Tuvalu, and the Marshall Islands are now routinely spoken of as countries "in the frontline of the impacts of climate change" (Carter 20I6, 2I3). For these countries, rising sea levels are eroding coastlines and infrastructure and contaminating freshwater sources in ways that threaten the very viability of long-term human populations there. However, even the larger Pacific Islands states are suffering from extreme weather events due to climate change. In recent years, powerful storms and cyclones have hit Solomon Islands (severe flooding in Honiara in 20I4); Vanuatu (Tropical Cyclone Pam in 2015); Fiji (Tropical Cyclone Winston in 2016); and Tonga (Tropical Cyclone Gita in 2018). In Papua New Guinea, the El Niño drought of 2016 brought famine and illness to hundreds of thousands of people in the highlands and other affected areas (Kanua and others 20I6).

The economic and social impacts of large-scale disasters on Pacific Islands developing states are immediate and severe, with long-term and complex consequences. For example, Cyclone Namu, which hit Solomon Islands in I986, destroyed much of the country's oil palm and rice production on the Guadalcanal plains. The damage to these agricultural industries then contributed to overdependence on logging as a source of government revenue, with devastating consequences for the nation's forests and its political order (Bennett 2000). The long-term economic and political impacts of Tropical Cyclone Winston on Fiji have yet to be tallied, but many locally produced agricultural products are at record prices and 
likely to stay high for up to two years (Simmons 2016). Severe flooding in December 2016 did further damage to areas already struggling to rebuild after Winston.

As the region suffers the effects of climate change, the governments of its small island states are becoming more vocal about the need for urgent global action to reduce greenhouse gas pollution. This poses new diplomatic challenges for Australia, the major development partner in the region. On the one hand, Australian governments want to maintain their hegemony in the Pacific by keeping cordial relations with the smaller island states. On the other, they are also committed to extending the life of Australia's troubled coal industry, an extremely powerful lobbying force that donates generously to the major Australian political parties (Carter 20I6; Morgan 20I7).

In the face of Australian government recalcitrance on climate change, disaster "management," "preparedness," or "risk reduction" have become the preferred language by which donors and recipient governments discuss responses to the effects of climate change in the region. Rendering events such as Tropical Cyclone Pam or Tropical Cyclone Winston as singular "disasters" and the region as "vulnerable to natural disasters" allows for official responses that do not consider climate change as a cause or amplifier of these disasters and do not address the implications of future intensifications of storms and cyclones or rising sea levels. Rather, international disaster discourse eschews blame, frames catastrophic events as natural phenomena, and allows government and nongovernment organizations' relief efforts to be incorporated into moral political narratives that construct Australia as a generous donor. (For example: "Australia will continue to be a generous friend to countries in need, responding rapidly and effectively to emergencies often caused by natural disasters in our region" [Bishop 20I3].) This is a conclusion that Island states have cause to question as they consider Australian moves to neutralize and delay effective global action on climate change. As we discuss in the next section, this questioning is already beginning at a popular level as Fijian Christians argue over the moral implications of Tropical Cyclone Winston and other disasters, as well as climate change itself.

\section{Paradise, Sin, ANd Moral Judgment}

Fiji is home to a large tourism industry, and, like almost all tropical tourism destinations, the imagery and language of tourism in Fiji presents the country in the familiar terms of the paradise myth as an unspoiled natural 
idyll (Connell 20I6; McDonnell, this issue). To some extent, Fijians have internalized these perceptions (Eräsaari 20I7). However, Indigenous ideas of the vanua (homeland) predate Christianity and have been integrated into Christian ideas about the nation and its people. Many contemporary Fijians (and other Pacific Islanders) look back to precapitalist, traditional society as an ideal of social harmony and prosperity that has been fractured by colonial dispossession and cultural dissolution (Tomlinson 2002; see also Rudiak-Gould 20I4). The contemporary Christian vanua has also incorporated aspects of the paradise myth in that Fiji is thought of as a blessed tropical land where its people may flourish without the burden of demeaning work or the constraints of a harsh environment. As Matt Tomlinson put it, the pre-Christian past is seen by some as a "Golden Age" (2002, I 59).

Alternatively, there is a pervasive counter-narrative that renders preChristian Fijians as savage cannibals, a theme familiar in Christian missions and now restaged for international tourists (Banivanua Mar 20I6). Both are versions of the familiar narrative of paradise lost: the story of the consequences of original sin. Just as the fallen Adam and Eve were cast out of the Garden of Eden, so too does the European transmogrification of Pacific Islanders from Rousseau's "noble savages" to savage cannibals perform the work of purifying paradise for colonial appropriation (Kabutaulaka 20I 5). In this scenario, paradise is lost by processes of expulsion and marginalization that then raise questions of how it might be regained. These imaginings are national in scale and require the collective Christian salvation of Fijians in order to redeem the nation.

Deckard has made a powerful case that the trope of paradise has been central to European projects of colonial capitalist expansion and the exploitation of both people and environments (2010). Promising a place of abundant wealth that is accessible with minimal labor, the paradise myth has mystified colonial relations of exploitation around the world. For Deckard, the paradise myth implies that prosperity is naturally found as a gift of God and felicitously harvested in tropical places and so is not understood as the appropriation of the cheap or forced labor of colonized people. With Indigenous labor rendered invisible by the paradise myth, noncompliant "natives" or "savages" then become "lazy," having failed to "improve" or "develop" their homelands in the way that modern European colonizers intended and promoted through plantations and broader capitalist transformations (Deckard 2010, 8-9).

The colonial tropes of natural bounty and native indolence are still alive 
in the Pacific, even among Indigenous populations. As Deckard made clear, colonialists' experiences of paradise were rarely fulfilled and, in practice, paradise was quickly lost or turned into an inhospitable anti-paradise of violence and struggle. While Deckard documented the malleability of the paradise myth, she did not trace the ways that the tropes of paradise and anti-paradise merge with Christian narratives of salvation history, an analytical perspective that we develop in the next section.

In the Christian tradition globally, and as it is interpreted in Fiji, paradise is a state of nature spoiled by original sin and then restored through salvation (Tomlinson 2002, I 58 ). This salvation history begins with the story of the fall in Genesis and is articulated fully by the apostle Paul in the Book of Romans (especially chapters 9-II). Paul is often turned to as a key figure in the development of Western individualism and radical change (Robbins 20I0), but there are also references in his writings that index ancient Israel as a chosen people central to Christian salvation history, which is understood as a thoroughly collective process of redemption.

The particular melding of Methodism and Indigenous traditions in Fiji has produced a popular nationalist rendering of this salvation history in which iTaukei see themselves as a chosen people inhabiting a promised land. This articulation of the paradise myth is grounded in collective Fijian history and emplaced in a particular, nationally delineated territory (Newland 2015). In this article, we explore how biblical salvation history can be mapped onto contemporary ethno-nationalist political projects. These projects are also reiterations of the paradise (or anti-paradise) trope in which the proper relations between people and God have been severed by original $\sin$. They suggest that until atonement is made and the right relationship with God is restored, Fijians will not be able to enjoy the full blessings of their paradisiacal homeland that God has set aside for them.

Methodists, Pentecostals, and the Holy Nation

Christianity in Fiji is dominated by the Methodist Church, which was established among Indigenous Fijians by Wesleyan missionaries in the early nineteenth century (Newland 2006; Tomlinson 2013). The Methodist Church has had a powerful historical role in shaping ideas of a Christian nation in Fiji, especially by drawing on biblical models of Israel as a chosen nation (Newland 2015). Particularly in the postcolonial period, iTaukei Methodists and other Christians have imagined themselves as custodians of a national patrimony over the vanua, which they see as threatened by the presence of the substantial numbers of Indo-Fijians (predominantly the descendants of indentured laborers and mostly Hindu, with 
Muslim and Christian minorities). Methodist leaders gave support to the I 987 military coup led by Sitiveni Rabuka and the church continues to have a powerful ethno-nationalist political role (Ryle 20I0).

In recent years, this political engagement brought church leaders into conflict with the military dictator Josaia Voreqe (Frank) Bainimarama, who was subsequently elected as prime minister by popular vote in the 20I4 national elections. Bainimarama has taken strong action to limit the influence of the Methodist Church, and he has been successful largely due to his ability to broker support from the various capital interests in Fiji, including Indo-Fijian businesses (MacWilliam 20I 5). Bainimarama's actions have included bringing legal proceedings against leaders of the Methodist Church for holding public meetings that allegedly contravened the repressive Public Emergency Regulations. This pressure forced the church to retreat from political engagement beyond representing immediate pastoral concerns (Newland 2016, I I4).

While Methodism remains the dominant institutional form of Christianity in Fiji, other churches such as the Roman Catholics, Anglicans, and Seventh-day Adventists were also founded locally in the nineteenth century. Since Fiji's independence in 1970, American, Australian, and New Zealander missionaries have established several new Pentecostal and evangelical sects, including conservative evangelicals such as various Baptist churches and the Salvation Army (see Newland 2006 for a comprehensive survey of religious affiliation in Fiji). The largest Pentecostal group in Fiji is the Assemblies of God church. Established in I926, they are one of the oldest Christian denominations in the country, to the point of being seen by some revivalists as too established and, like the Methodists and other mainline churches, as lacking in dynamism (Newland 2006, 358). As is typical of trends worldwide (Robbins 2004b), the enthusiastic and less-formal styles of worship-including the use of Christian rock music-in newer Pentecostal groups attract younger people and have become practices that mainline congregations adopt as an index of Christian vitality and newness (Tomlinson 2013).

Pentecostalism has a universalistic outlook and offers its followers the promise of partaking in a fulfilled and bountiful experience of modernity, as Karen Brison has argued (2007, $32 \mathrm{ff})$. This involves learning new disciplines of the self that include intense moral self-scrutiny and restructured social relations grounded in companionate marriage and the nuclear family (Cox and Macintyre 20I4; Newland 2006). Pentecostal univer- 
salism is also strongly focused on evangelism (Robbins 2004b). In Fiji, new members are largely drawn from Methodist, Assemblies of God, or other older Christian churches, but Pentecostal ministries do aspire to be racially inclusive, attempting to attract Indo-Fijian converts and conducting services in Hindi (Morgain 20 I 5). In this context, race and culture are to be replaced by the "Kingdom of God culture": the disciplines of Christian devotion and evangelism practiced by true Christians.

The stress on personal salvation, career, and family life notwithstanding, Pentecostals still retain influential Fijian Christian cultural undercurrents that flow back into ideas of an Indigenous Christian nation. For example, in the eyes of some Pentecostals, iTaukei are regarded as having a particular relationship to Christianity as a faithful and spiritual people, unlike the "backsliding," secular West. These qualities elevate Fijians' position in the world, as they now see themselves as having a mission as exemplary Christians (Brison 2007, 33-34). Set in a regional context, this is a remarkable contrast to the "negative nationalism" documented by Joel Robbins in Papua New Guinea (2004a), where Urapmin evangelicals define themselves as sinners in explicitly racialized terms (see also Bashkow 2006; Cox 20I5).

Despite the rapid growth of Pentecostal groups, the Methodist Church remains the dominant Christian denomination in Fiji. Most Pentecostal churches focus on individual salvation and eschew active involvement in politics, but some may enter the political domain, particularly in relation to debates on moral issues (Newland 2006, 382). One of the more influential evangelical groups in recent years has been the New Methodist Church, a Pentecostal movement that broke from the Methodist Church. In the early days of Bainimarama's military government, the New Methodist Church was closely aligned with the police force because its charismatic founder, Atunaisa Vulaono, was the brother of the then-police chief. Under his leadership, several evangelical Christian practices were imposed on police officers, even those who were not Christian. This sectarianism eventually led to conflict between the New Methodist Church and the Bainimarama government (Tomlinson 2013). Nevertheless, the church still enjoys a strong following among young people. The New Methodist Church, like other Christian groups, campaigns for Christian leadership of the nation, which they understand as quintessentially Christian and grounded in their belonging to the vanua as a promised land of blessingsa provisioning paradise. 


\section{The Impact of Tropical Cyclone Winston}

On 20 February 20I6, Fiji was hit by Tropical Cyclone Winston, a category five cyclone and one of the strongest cyclones ever recorded in the Pacific region. Winston's impact on Fiji was severe, with heavy rains causing flooding and landslides, and extremely powerful winds of up to 350 kilometers (2I7 miles) per hour creating storm surges and doing immense damage to property, including some thirty thousand private residences as well as other resources. Winston disrupted power supplies and water and sanitation systems, leaving tens of thousands of Fijians without potable water. Forty-four people were killed and thousands of families were left homeless. Winston caused an estimated us\$460 million in damage (Varandani 20I6).

As is now typical of responses to disasters of this magnitude, the international relief effort was rapid and substantial. Australia, Fiji's largest trading partner, provided the largest humanitarian assistance to Fiji, totaling $A \$ 35$ million (Us $\$ 27.6$ million), including Australian defense support until April 2016 (DFAT 20I7). New Zealand provided financial and defense support as well, amounting to NZ\$5.47 million (Us\$3.97 million). To raise additional funds, the Fiji government, in conjunction with the United Nations, launched a three-month, us $\$ 38.6$ million flash appeal. The appeal, which ended on 2 I May 20I6, raised Us\$19.8 million (5 I percent of the target) and proved to be the best-funded emergency response in the world in 2016 (United Nations Office for Humanitarian Assistance 20I6). Aid was also provided by other countries, international organizations (eg, Red Cross), and local companies and community groups (eg, Fiji Airways contributed Us\$I million).

The Fiji government requested that nongovernment organizations (NGOs), humanitarian agencies, and donors coordinate their relief efforts with the National Disaster Management Office. However, this did not apply to smaller-scale activities, such as the crowdsourcing pages that were also created to raise funds for victims of Tropical Cyclone Winston as the nation mobilized to respond to the disaster. This informal activity reached a point where there were too many organizations and individuals wanting to provide some form of assistance, for instance donations of clothing, to those affected. Villagers reported that they did not need so much extra clothing and instead requested money for materials with which to rebuild their homes (Brennan 20I7). 


\section{“Stronger than Winston” Versus Conspiracy Theories}

Immediately following the cyclone, the catchcry "Stronger than Winston" spread quickly around Fiji. The first use of the hashtag \#StrongerThanWinston was from the official Twitter account of the Fiji Ministry of Rural and Maritime Development and National Disaster Management on 20 February 2016 at I2:30 PM. The slogan invoked a national community that rallied to support people in devastated areas and to help rebuild houses, schools, and other infrastructure. The phrase "Stronger than Winston" spread rapidly and was taken up enthusiastically in urban settings as the middle classes repeated the slogan in the fund-raising activities they held for rural communities affected by the cyclone.

Despite its broad appeal, "Stronger than Winston" did not sit comfortably with some evangelical Christians who regarded the cyclone as an act of chastisement from God. For these groups, the claim that the community was "Stronger than Winston" was a hubristic and anthropocentric claim that ignored divine agency and therefore diverted attention from the urgent need to demonstrate a humble disposition toward God through public acts of repentance. For example, one iTaukei woman's February 2016 contribution to the Taukei kei Viti ("the owners of Fiji", a conservative forum) Facebook group, just a few days after the cyclone had hit, warned: "When YHWH brings calamities and wishes for HIS people to follow HIS laws for their blessing but the people reject HIM and proclaim ... "We shall rebuild", instead of humbling themselves they bring upon themselves another calamity far worse than the first because they refuse to listen."

As noted earlier, interpreting natural disasters as an act of divine judgment is an ancient practice in Christianity and many other religions. In Western Christendom, this religious tradition has receded to the margins of public debate since the eighteenth century, when Rousseau and Voltaire argued about the impacts of the great Lisbon earthquake of I 755 , dismissing theological readings of the catastrophe (Fountain and McLaughlin 2016, 2-3). Secular state and NGO disaster management practices derive from this shift in perspective and rarely acknowledge local perceptions of divine agency. Nevertheless, as the articles in Phillip Fountain and Levi McLaughlin's 2016 collection show, religious interpretations of "natural" disasters are highly important for understanding local and national responses to these disasters in many contexts outside the West, including the Pacific. 
Christian narratives of judgment and disaster are not new to Fiji. In 2OI2, severe flooding hit Nadi, the center of Fiji's tourist industry, causing great disruptions to air services and local infrastructure. Our research team observed numerous iTaukei Christians who claimed that the floods were an act of God's judgment, punishing the permissive sexual behavior allowed by the tourist industry. Drawing on the biblical story of the destruction of Sodom and Gomorrah, some Christians singled out homosexuals as the primary reason for the flooding. These interpretations saw homosexuality as a foreign practice that compromised the moral integrity of the Christian vanua. While the tourist imaginary of paradise renders tropical islands as places of natural bounty and innocence, for some iTaukei Christians, tourism is evidence of an anti-paradise of moral corruption that brings divine chastisement.

Others regarded the impact of the $20 \mathrm{I} 2$ flooding on the tourism industry as evidence of God's chastisement taking a particularly economic turn in punishing the Bainimarama government. This political interpretation of divine judgment was also prominent after Winston and was linked by some to the 2013 constitution, which makes Fiji a secular state. As one contributor to the Taukei kei Viti Facebook group (April 20I6) complained: "This very action [the new constitution] desecrates the traditional leadership of this country and denied God His sovereignty over it, just like what the Israelites did. Fiji has begun to have a taste of the wrath of God and it will continue until we repent our sins."

In this political reading of disasters, as in the homophobic variant, the vanua is a paradisical promised land, a home to the chosen people that is both a physical territory and a moral community. We return to these themes in subsequent sections of this essay.

As Phillip Fountain, Sara Kindon, and Warwick Murray have demonstrated (2004, 339; see also Trompf I994), conspiracy theories often proliferate in the aftermath of disasters as people struggle to make sense of a disordered social world. Here we follow Harry West and Todd Sanders in seeing conspiracy theories as accounts of how the world works that “express profound suspicions of power" $(2003,7)$. In these accounts, natural, supernatural, and political powers overlap and merge. Some idiosyncratic local-level theories emerge, such as the idea that the I998 Aitupe tsunami was the result of a bomb detonated by foreigners who were intent on taking Papua New Guinean land (Fountain, Kindon, and Murray 2004, 340). However, as various conspiracy theories circulate, they go through a process of social refining in which those that do not 
resonate with a wider audience lose their currency and tend to be replaced by alternative explanations that reflect a larger consensus of shared views.

Moral judgments of particular island or regional groups within Fiji circulated after Winston in private conversations among families and groups of friends, but these did not become established as public interpretations of the cyclone. Some Christians speculated that the areas hit by Winston were populated by people who were prone to committing characteristic types of sin, thereby mapping regional reputations onto the path of the cyclone. Household discussions observed by Finau and Tarai in 2016 concerned Koro, a small island in the Lomaiviti group of Fiji near the main island of Viti Levu, and one of the hardest hit by the cyclone. The Methodist informants described with awe the tsunami-like waves produced by the cyclone and strong winds that blew down concrete houses. They then immediately shifted into a moral assessment of Koro's inhabitants as arrogant people who do not observe the Sabbath. One senior man from another district complained to Tarai: "They [the people of Koro] drank too much grog, even moving into the Sunday morning hour as a regular practice ... this is why they got heavily devastated. They did it to themselves, turning from God.”

However, this judgment was implied rather than made directly and stayed within the household without becoming a generalized interpretation of the disaster that circulated nationally.

Other Fijian groups have stereotypical moral failings attributed to them that could potentially have been drawn into a narrative of divine judgment. For instance, for some Fijians, Taveuni is considered a notoriously promiscuous island, and $\mathrm{Ra}$ is often described as the center of black magic in Fiji. However, these expressions of intra-Fijian rivalries did not scale up to become a national discourse. In the case of the household discussions among Suva Methodists observed by members of our research team, these conversations were characterized as petty jibes and were not thought appropriate for a disaster of Winston's severity. Given the scale of suffering, the Fijian Methodists making these casual remarks at home were not willing to utter public statements, as these would be considered insensitive and judgmental. However, similar disparaging characterizations were used by some Pentecostal preachers in sermons as evidence of national malaise being punished by a righteous God.

In Fiji, a YouTube video was circulated widely on Facebook claiming that Tropical Cyclone Winston was "geo-engineered," as proved by the supposed evidence of residual "chemtrails" (Rob D 20I6). "Chem- 
trails" are believed by some far-right libertarian groups in the United States, Australia, and elsewhere to be poisons sprayed across the earth by governments as a means of controlling populations and manipulating weather (Dunne 20I7). Like religious explanations of disasters, the chemtrails conspiracy attributed the cyclone to the intentions of powerful external agents. While this pseudo-scientific explanation of the cyclone certainly found an audience in Fiji, it failed to actually name any perpetrators, leaving this to the imagination of those who followed the theory.

The chemtrails theory appeared to offer an explanation of Tropical Cyclone Winston but, in the end, it did not succeed in grounding its conspiracy in other social concerns in Fiji. Some Fijian Christians did attempt to incorporate chemtrails into a broader narrative of God's judgment but merely as the (pseudo-) scientific means by which God had exercised his wrath. The chemtrails themselves thus lacked the social meaning required of a satisfying explanation. After Fijian meteorologists published a scornful rebuttal in a subsequent Facebook posting (NaDraki Weather 20I6), support for the theory waned. This may have been more about the emptying out of any remaining explanatory value of chemtrails, or the class influence of respected national professionals, than an example of scientific debate.

If the chemtrails conspiracy theory failed to relate to wider concerns in Fiji, it may be because it imagined an international scale that was emptied out of any specific actors (was it China? Russia? the United States?). By contrast, interpretations of Winston that had greater longevity focused on a national scale, including both the rallying cry of "Stronger than Winston" and the view of the cyclone as God's chastisement of his chosen people. We return to these questions of scale and blame when discussing climate change later in this article.

\section{Covenant and Chastisement}

By focusing on rebuilding and national solidarity, "Stronger than Winston" left little room for interpretations of the cyclone as God's judgment on a sinful people. For fundamentalist Christians, this was a failure to exhibit the appropriate demeanors of humility and repentance that allow the forgiveness of sin and the return to God's favor. Key Old Testament texts, such as 2 Chronicles 7:I4, are thought to set out the paradigm of post-disaster humility and repentance. As another iTaukei woman posted 
in the Taukei kei Viti Facebook group in March 2016: "on some comments saying We are stronger than cyclone Winston. 'unquote' Plse remember our creator who create the cyclone. 2 Chronicles 7:I4 If my people who are called by my name will humble themselves, pray, seek my face and turn away from their wicked ways, then I will hear from heaven and will forgive their sin and heal their land."

In the eyes of some iTaukei, the cyclone was a punishment for the breaking of a particular agreement or covenant between God and Fijians. Fijians have long modeled their national identity on ancient Israel, interpreted in the Old Testament as a "chosen people" who enjoyed a unique, salvific relationship to God. This understanding has its roots in early interactions between Methodist missionaries and Indigenous Fijians (Jones 20I5; Newland 20I5). In the March 2016 Facebook group discussion that followed the 2 Chronicles quotation above, another group member made explicit the link between the cyclone and Fijians as having broken the covenant with God: "Whatever is coming is coming. The point is Fiji needs to rededicate itself to the creator. The natives need to wake up for the curse is upon them and was on their forefathers too. It is not on the foreigner: they too will share in the heartache. We are the ancient ones who made a covenant with God and have broken it. The covenant is evident in our male circumcision. It was down [sic] with Abraham and is alive for all generations."

These sentiments were echoed in other forums. Immediately after the cyclone, another iTaukei women posted in the Fiji Native Tribal Congress Facebook group, referencing the biblical punishment of the Israelites and interpreting the disaster as a spiritual purification:

For the $4^{\text {th }}$ day now watching posts on the aftermath of TC Winston, I cannot help feel G-D's Great Strict Love to us His children. Just as the Israelites faced during the Exodus and post Exodus when they rebelled against His statutes, commandments, decrees, covenant, etc they faced the brunt of G-D's grave strict love. How else can we achieve fullness of life if we are polluted. We have gone astray and missed opportunities given to us to repent and return to Him our source, our rock and refuge, our root, our foundation, our mana, our yavu [foundation] (I Corinthians 3:I I).

Our physical foundation, yavu, roots, mana has just gone through G-D's deep and strict cleansing, purification, smelting and deep painful polishing. Praise be to G-D. In our current purified state, just like the Israelites after a strict cleansing RETURN to Him and to our G-D given inheritance and we will have his favour. 
The following long prophecy also illustrates the view that Fiji (understood as a nation of iTaukei) has a covenant with God that, like the biblical covenant between God and Israel, can be broken by sin at the cost of disastrous punishment. The prophecy comes from the website of a Pentecostal church called "The Rock." This church has several congregations in Fiji and is typical of neo-Pentecostal groups with an emphasis on personal salvation and the imminent return of Christ (Robbins 2004b). It is led by a Fijian who styles himself as a prophet and who has taken the name of Jeremiah. Like those of the biblical Jeremiah, his prophecies predict destruction and suffering for the chosen people in the face of their stubborn refusal to turn from sin.

PROPHECY 4 (May 20I5)

Fiji as a nation will go thru the fire.

Tough times are ahead for us.

We may have to cry and be sorrowful!

Weeping may endure for a night but joy comes in the morning!

The fire will burn what needs to be destroyed and leave what will stand!

What will stand is the sure word of God.

God is the only one that knows our tomorrow and only one that speaks things

into existence.

All in all God stands alone!

REMINDER

Fiji is a covenanted nation unto God.

A covenant cannot be broken by someone outside of this covenant.

When someone violates the covenant trouble starts!

Covenants are powerful stuff.

And ignorant people that comes against it get hurt.

Because they don't understand that they are coming against God.

Scary stuff!

Covenanted people and nations that stray from covenants with God, suffer great judgements.

\section{CONCLUSION}

What is going to happen in Fiji will affect the whole world and also the church of the living God.

It affects the rapture of the church and all of eternity.

We are looking at the harvest at the end of the age for the church of the living God. 
From the time of Jesus and the Apostles this is that generation and this is that final harvest.

So as far as the kingdom of heaven and the kingdom of God is concerned this is so so so important ...

God is not going to come as a wimp.

God is coming as a LION!

The battle is not ours church.

The battle is the LORD'S.

(Waqa 20I5)

While this prophecy was issued a full year before Tropical Cyclone Winston, Jeremiah has issued more recent proclamations that make the link between the cyclone and God's judgment explicit: "Most of the villages that suffered in the Winston hurricane, received their dose of judgment from above, because of the practices of witchcraft and sorcery? Judgement came down because of gross evil and wickedness. Because of iniquities and sin?" (Waqa 2016).

These "iniquities and sin" are standard tropes that, for Jeremiah, point to the unfaithfulness of the nation and its leaders with the consequence that God will punish them. As noted earlier, while Methodists also circulated similar stories in private conversations, they were more careful in making such accusations in public. In 20I7, Jeremiah also preached directly against Prime Minister Bainimarama: "The longer the Bainimarama government prolongs the handover [to an unnamed Christian leader] the worst [sic] things will be for them and for the nation of Fiji" (Waqa 20I7).

The articulation of these Christian, nationalist ideas by Pentecostals provides an explicit foundation for their public interpretations of Cyclone Winston as an act of divine punishment. This kind of punishment can be read as a mode of purging paradise, akin to the expulsion of Adam and Eve from the Garden of Eden. The Fijian vanua cannot realize its historic destiny of paradise regained until its unfaithful leaders are removed and the people repent. These pronouncements have an explicit political tenor that is based on a critique of the Bainimarama government's secular and "nonracial" constitution.

Interpreting natural disasters as divine judgment is by no means peculiar to contemporary Pentecostals and evangelicals; John Wesley, the founder of Methodism, believed that the Lisbon earthquake of I755 was an act of God's judgment (Chester and Duncan 2010, 86). However, contem- 
porary mainline church leaders are unlikely to voice such views even if the members of their congregations hold them. This is partly because of theological developments since Wesley's day, but it also reflects the place that mainline churches have in the modern public realm where such views are regarded as repugnant for their lack of compassion. A pastoral letter written by theologian Reverend Dr Cliff Bird, a Solomon Islander working for the Methodist Church in Fiji, makes this clear (Bird 20I6). Bird's letter was circulated by the Methodist Church in the wake of Tropical Cyclone Winston and argues against interpretations of the cyclone as an act of judgment, instead urging all Fijians to be compassionate to the victims of the disaster. Warning against narratives of judgment, Bird wrote: "It is unfortunate that many people today, including teachers and preachers of the gospel, often resort too quickly to spiritualistic explanations, and associate natural calamities and the resultant loss and destruction with divine rebuke and punishment, or as coming from God thus causing fear and confusion" (Bird 2016).

Pentecostals are not lacking in compassion, but within the public realm they occupy a very different position from the mainline churches, which have a long history of interaction with the state. Pentecostals largely seek to recreate the public realm in their own image, often seeing the state as simply a resource for evangelism. In Fiji, the nation is imagined by preachers such as Jeremiah through biblical analogies with Israel (Jones 2015; Newland 2015) and thus as a promised land-a variant of the paradise trope. Therefore, they do not have the same type of civic engagement as other churches; they seek to create Christian citizens of the Kingdom of God rather than to be part of civil society or contribute to secular nation making. This focus on creating their own "Pentecostalite public realm" (Meyer 2002, 69) means they are less constrained by considerations of whether their views might seem callous, extreme, or simply gauche. Consequently, they have more freedom to air views that speak to their own followers and theological preoccupations, even if others may condemn them as parochial, judgmental, and lacking in empathy for the victims of disasters.

\section{The Political Dimension of the Chosen Nation}

Proclamations of Fiji as a chosen nation are not mere spiritual fantasies but have a particular political edge in the present day. According to some variants of this thinking, when the chiefs of Fiji ceded their land to the 
British Crown in 1874 , they did so dedicating the country to God as a Christian nation; in short, they formed a covenant (Brison 2007, 35-36). Others assert genealogical links and claim Jewish ancestry for Fijians as the descendants of the lost tribes of Israel, remaking Christianity not as rupture with Indigenous thought and practice but as a religion with ancient continuities that allow it to integrate into and reform iTaukei traditions (Presterudstuen 2016). Sitiveni Rabuka, the leader of the I987 military coup in Fiji, justified his intervention by referring to Fijians as the chosen people and claiming Jewish ancestry for iTaukei (Newland 2OI 5).

For many iTaukei Christian nationalists, the 2013 Fiji Constitutionenacted by the military government led by Bainimarama-affirms the idea of a secular nation-state and thus forfeits the vision of a Christian Fiji while sidelining the Great Council of Chiefs. Support for a Christian state under the control of iTaukei is widely held and features in debates concerning the party platform of sodelpa (the Social Democrat Liberal Party), the largest opposition party (Newland 20I6, I2I). In 20I2, the conservative political party Soqosoqo Duavata Ni Lewenivanua (SDL, the predecessor party to SODELPA) made a formal submission to the constitutional commission arguing that Christianity should be the state religion of Fiji because of historical precedent: "Why 'Christianity' as the state religion? There are several reasons in support of this proposal. First, our High Chiefs who ceded Fiji to Great Britain in I874 wanted to secure '. . . the promotion of civilization and Christianity' alongside trade and industry, order and good government for the people of Fiji. Second, 'Christianity' was the first religious faith to be introduced, and accepted by Fijians in I 835 . And third, more than half of the population of Fiji now is Christians, making Christianity the largest religious faith in the country" (SDL 2OI2). The party then campaigned against the $20 \mathrm{I} 3$ constitution in its 2014 election manifesto, painting it as a "Godless Constitution" (SODELPA 20I4). This rhetoric, equating secularism with the rejection or absence of God, has been a feature of iTaukei debates about the constitution for several decades (Newland 2016, I I3).

In the wake of Tropical Cyclone Winston, some iTaukei nationalists see the 2013 constitution as an act that has broken the covenant and thus has provoked God to unleash His wrath, disciplining His chosen people. Like the biblical Israelites, iTaukei are a chosen people and suffer severe chastisement through natural disasters that are intended to remind them of their obligations to God. Some Christian commentators have noted that 
the effects of the cyclone fell more heavily on the iTaukei population than on the Indo-Fijians and interpret this as evidence of God's intention to punish and discipline His chosen people who have turned away from the correct path. In the words of a retired public servant posting on the Taukei kei Viti Facebook site (April 20I6): “Therefore, one should not question why the native Fijians have suffered the most. Yes, the native Fijians had the power in leadership and military might to stop this desecration but they chose not to because they were already enjoying the economic return of such devious actions."

In these contemporary narratives, the offending collective sin is not the reversion of Christians to pagan ways (Newland 2004). Rather, these narratives offer a political critique of the Bainimarama government, particularly its treatment of church leaders, rejection of chiefly authority, and embrace of Indo-Fijians. As an Indigenous leader of the nation and its military forces, Bainimarama is seen as uniquely responsible for iTaukei apostasy, a spiritual parallel to the ancient Israelites who turned away from God by breaking the covenant and who were therefore punished by being cast into exile.

These narratives of divine judgment contain a logic of moral blame. Disasters are not simply natural events but occur because of the intentional agency of a powerful figure-for Fijian Christians, God. The blame is assigned according to the scale of the disaster. In the case of a national catastrophe like Tropical Cyclone Winston, national figures such as the prime minister became focal actors whose political decisions were seen as challenges to the imagined Christian moral covenant with God; thus, they were to blame for the wrath that followed. In the next section, we explore how a similar logic of blame is scaled differently when considering climate change responses in the Pacific.

Before proceeding further, however, it is important to take note of Fountain and McLaughlin's caution that "not all practices of relief emerge out of clearly formulated ideational frameworks" (2016, 9). In Fiji, believing that a natural disaster is divine punishment does not stop Christians from providing assistance to cyclone victims. The practical responses to disasters such as Tropical Cyclone Winston have been universally compassionate, even among those who believe the cyclone to be evidence of the wrath of God. The logic of blame has its limits and these seem to be easily overridden when confronted with the moral reality of being required to respond to others' suffering. 


\section{Climate Change, Scale, and Narratives of Blame}

Natural disasters in the Pacific are now commonly framed at a governmental level through an overarching narrative of climate change, even if Pacific populations do not always share this perspective (Mortreaux and Barnett 2009). Climate narratives are not merely technical descriptions of the scientific state of the world but also carry moral and political implications (Hulme 20I4). Climate change discourse makes sense of natural disasters by locating them as intelligible and significant events within an anticipated (or dreaded) trajectory of ever more frequent and increasingly severe extreme disasters. Some have accused climate activists of schadenfreude (pleasure in others' misfortune) in their efforts to locate environmental disasters such as rising sea levels within the sequence of climate events (eg, Farbotko 2010).

For many Pacific Islanders, the prospect of losing their homelands to rising sea levels caused by climate change is manifestly unfair given the paltry contribution that Pacific populations have made to greenhouse gas emissions. This recognition underlies much contemporary diplomacy in the Pacific. Pacific Island states are now beginning to realize that Australia, their traditional development partner, is politically committed to prolonging the life of its own fossil-fuel industry regardless of the longterm impacts that climate change will have on the Pacific (Maclellan 20I7; Morgan 2017; Fry and Tarte 2016).

Following the election of the avowed climate-denialist Donald Trump as president of the United States in November 20I6, Fijian Prime Minister Bainimarama implored the president-elect to accept the scientific consensus on climate change and invited Trump to visit Fiji to meet with victims of Tropical Cyclone Winston (Radio New Zealand International 20I6). In doing so, Bainimarama gave public expression to a new "common sense" in relation to climate change in the Pacific Islands: Pacific Island leaders now see natural disasters as the effects of climate change. Moreover, it is the people of the Pacific who are the victims of the decisions made by global powers. These narratives have been deployed successfully in organized lobbying at international meetings on climate change (Carter 2016). The effectiveness of these efforts can be seen in the fact that, already, climate denialists are seeking to discredit Pacific leaders as rent-seekers using climate change as a pretext for more aid money (eg, Lomborg 2016). Arguments for international assistance to the primary victims of climate change 
are being countered by attacks on their moral worthiness to receive such aid. Global climate activists such as Naomi Klein have reasserted the reality of the effects on the atoll states (Klein 20I6). Bainimarama introduced a political and moral dimension into these debates by characterizing Australia as leading a "coalition of the selfish" (Morgan 20I7), referring to a group of other industrialized nations that refuse to abandon their fossil fuel-based economies. Here, at a Pacific regional scale, the logic of blame accrues to the regional hegemon within a geopolitical context where Fiji wants to exercise more influence within the region.

While the association of disasters with climate change is very clear at a governmental level, this connection is not always made at a popular level (Lata and Nunn 20I2, I80). Nevertheless, these ideas are also spreading rapidly among broader Pacific publics (Titifanue and others 20I7). Through social media, many of these international debates are taken up by Pacific Islanders themselves, although rarely with the political edge that Bainimarama deploys against Australia. Around the Pacific, moral narratives of climate change also circulate at a popular level. Moreover, they are being integrated into religious interpretations of natural disasters as punitive or minatory acts of God. In a debate about Tropical Cyclone Winston on the Taukei kei Viti Facebook group (April 20I6), one contributor, the retired public servant quoted earlier, took the Fiji Sun newspaper to task for dismissing religious interpretations of the cyclone as God's wrath by claiming that the newspaper's alternative explanation, namely climate change, was also a manifestation of God's wrath and followed a biblical precedent:

Some religious-minded people, like me, are beginning to or had already analysed the two natural disasters that have befallen Fiji as driven by the wrath of God. The unbelieving Fiji Sun and many others have called this thought idiotic and blamed it on climate change. Lest these unbelievers do not realise that even climate change is the wrath of God given that mankind has disturbed the balance of nature by his stupid manipulations of the environment. Surely the Fiji Sun is not as naive as it proclaimed. However, from a biblical context these calamities are similar to what befell the Israelites when they turned away from God and worshipped idols and sinned in front of God.

In these post-Winston discussions of climate change in Fiji, humans are seen as having broken natural laws, which then incurs environmental consequences. These are sometimes mentioned as disturbing a balance (as discussed earlier in this article) and at other times as damaging the envi- 
ronment through pollution. One Pentecostal iTaukei woman posted in a February 2016 Fijian Facebook discussion of chemtrails, rejecting the geoengineering premise of the chemtrails conspiracy as an anthropocentric denial of the consequences of breaking the natural laws that God set in place: "Of course Winston is man made by every single one of us, yes you and me. All these man made stuff created has damaged our environment. Weather changes is drastic now due to years of our neglect and abuse via pollutants. All these years of abusing mother earth and to think nothing will happen? . . . Because GOD commands the winds and the waves!!! Who are we to give man that high honor of praise!"

While God sits at the top of this chain of dire consequences, these ideas clearly begin with scientific understandings of climate change that are nested within a Christian framework of fallen humanity: the paradisiacal created order of nature disturbed. This is a more generalized articulation of $\sin$ and environmental disruption than those that link Winston to iTaukei Christian nationalism. However, the Christian objections to "Stronger than Winston" follow the same logic wherein the ultimate cause of disaster is human arrogance through which people are perceived to have placed themselves above their appointed position in the moral order of the cosmos.

The logic of blame in ethno-nationalist accounts of divine judgment is quick to identify sinners or political leaders who are responsible for offending God and provoking his wrath. However, as the connection is then made with climate change, a shift has already taken place, bringing the conversation into a global scale where the logic of blame does not find individuals guilty so much as the entire human species. This generalized blame echoes Christian theological principles of fallen humanity, where sin entered the world through the disobedience of Adam and Eve in the Garden of Eden, requiring them to be expelled from the ease of paradise into a world of struggle.

Just as the chosen nation endures chastisement for turning away from God, the logic of blame and punishment is applied to a global scale where the human species-not the nation-is the unit of blame. David Lipset has argued that climate change represents a new "chronotope" (organizing category) that proliferates ideas of "global risk," displacing modernist framings of the state: "Because global risks are understood as incalculable, unlimited, and unaccountable, and their location in space and time is global, rather than territorial, both local agency and modernist sovereignty become problematic" (2OII, 2I). 
Lipset's analysis helps us to understand why Christian Fijians switch scales of reference as they move from discussing Tropical Cyclone Winston (a national disaster) to climate change (a global risk). Whereas Lipset characterizes global risks as incalculable, here we take a further step by drawing out the implication of incalculability for questions of moral blame. We suggest that, just as global risks are incalculable, so too do they become much more distant and difficult for ascribing culpability. Global risks are not only incalculable, they are also inculpable, as blame is diffused over a global scale in which no one is personally responsible and where collective responsibility is also diluted to include the entire human community. This dissolving of blame across the global scale amounts to a kind of environmental original sin where all have sinned and are fallen.

Peter Rudiak-Gould has argued a similar case for Marshallese responses to climate change, distinguishing two related logics of blame (20I4). The first, "industrial blame," lays primary responsibility for climate change with the industrialized nations that have contributed the most pollution historically. This is a narrative of blame accepted by most anthropologists who study climate change and is often repeated by climate activists. The second logic of blame, "universal blame," sees climate change as a generalized effect of human nature and desire for modern consumer goods and lifestyles-an awareness that everyone emits greenhouse gases and therefore bears responsibility for climate change.

According to Rudiak-Gould, Marshallese are reluctant to blame "the West" for climate change and insist that they too must do their part by reducing their own personal emissions. Rudiak-Gould argues that Marshall Islanders have adopted this second view and so see themselves as also blameworthy and therefore as needing to take action by changing fuel sources or by adopting disciplines of environmental citizenship such as avoiding polystyrene cups. He locates this logic of blame within existing Marshallese narratives of cultural decline that critique the adoption of foreign customs and consumer tastes. Fijian Christians also seem to accept this logic of universal blame for climate change, although they are more specific in ascribing culpability for Tropical Cyclone Winston to Prime Minister Bainimarama.

Nevertheless, as Rudiak-Gould argued, "universal blame” or "selfblame" perspectives do not mean that Pacific Islanders are unaware of the responsibilities of industrialized countries and their legacy of disastrous pollution. At an intergovernmental level, climate change is of great 
concern to Pacific Island nations, and the intransigence of Australia on climate threatens to open an unprecedented rift between the region's largest donor and its Pacific Island "neighbors." However, in the popular imagination, Australia and New Zealand are helpful "big brothers" who come to the assistance of Fiji in times of need, providing equipment, supplies, and skilled disaster response teams. The generous Australia that provided $\mathrm{A} \$_{\mathrm{I}}$ billion of disaster response after Tropical Cyclone Winston is bracketed off from the ruthless Australia whose politicians are committed to protecting its coal industry regardless of the risks to a safe climate.

What is remarkable in these popular narratives is the absence of political economy. By diffusing blame across the entire human species, the culpability of particular actors (eg, industrialized nations, fossil fuel companies, and their deeply embedded lobbyists) is occluded. Environmental original sin becomes an erasure of the agency of powerful and destructive actors. Margaret Jolly has described this as "the fig leaf of the "we"' where claims of shared humanity conceal the uneven and unfair effects of climate change as its impacts fall most heavily on the global poor (20I8). These analytical shifts can be seen as a variation of the effects of paradise discourse in Deckard's argument that the natural and abundant blessings of tropical colonies (as paradise) were imagined as producing prosperity in ways that concealed the agency of colonial powers in exploiting native labor (Deckard 2010).

Even when the destructive impacts of industrial economies are acknowledged, even very progressive Fijian Christians typically stop short of blaming particular actors. In an article titled "Jesus and Climate Change" (20I7), Reverend James Bhagwan, a Methodist minister, reflected on Easter Sunday celebrations among Christian youth that had had the theme "rising hope during rising tides" - a theme chosen to address climate change directly as a Christian theological problem. In a reference to climate change, Bhagwan acknowledged that "our planet is being crucified by the powerful, its greatest consumers" and went on to catalog a number of impacts of climate change that will be permanent. Following the theologian William Brown, Bhagwan likened the wounds on the body of the risen Christ to the permanent damage that climate change will do to the Earth. Christians see Christ's crucifixion primarily as the unfolding of salvation history, not as an historical event that the Romans should be blamed for (although of course a profoundly ahistorical anti-Semitic tradition within Christianity has blamed "the Jews" for Christ's death). In a similar logic, 
Bhagwan's ecological theology looks not to blame industrial polluters but rather to see a cosmological purpose that redeems the damage done to the planet's ecosystems and people. Inasmuch as there is a narrative of blame here, it is the logic of universal blame, articulated within a cosmological scale of salvation history that has moved well beyond the nation-state or even the human race to embrace the whole of creation.

\section{Conclusion: Paradise and Anti-Paradise}

Tropical Cyclone Winston has provided another opportunity for debates about the moral causes of disasters among Indigenous Fijian Christians. These debates center on a salvation history in which Fijians identify themselves as a chosen people inhabiting a paradisiacal promised land or vanua. Understood as grounded in a physical territory and embodied in a moral community, this salvation history invokes a logic of blame that makes contemporary politicians responsible for the nation's spiritual well-being. In these narratives, Fiji's idealized past and hoped-for future are rendered in terms of paradise, while the present is a moral tale of Paradise Lost.

As natural disasters are increasingly understood as manifestations of climate change, interpretations shift to a global scale where local or national agency and logics of blame diminish in relevance. Already some Pacific Islanders-particularly leaders such as Bainimarama or the president of the Republic of the Marshall Islands, Dr Hilda Heine-do publicly attribute blame for climate change to heavy-polluting countries such as Australia and the United States (Morgan 20I7). However, in Christian Fiji, while the immediate political impact of Tropical Cyclone Winston may undermine confidence in the Bainimarama government, it will not necessarily generate widespread demands for climate justice. This case therefore provides a contemporary variation of Deckard's thesis that the paradise myth enables exploitative relations of colonial dispossession.

\section{References}

Alexeyeff, Kalissa, and John Taylor, editors

2016 Touring Pacific Cultures. Acton, ACT: ANU Press.

Banivanua Mar, Tracey

2016 Performing Cannibalism in the South Seas. In Touring Pacific Cul- 
tures, edited by Kalissa Alexeyeff and John Taylor, 323-33 I. Acton, ACT: ANU Press.

Bashkow, Ira

2006 The Meaning of Whitemen: Race and Modernity in the Orokaiva Cultural World. Chicago: University of Chicago Press.

Bennett, Judith

2000 Pacific Forest: A History of Resource Control and Contest in Solomon Islands, c. I800-I997. Leiden: Brill Academic Publishers.

Bhagwan, James

2017 Jesus and Climate Change. Fiji Times, I9 April.

Bird, Cliff

2016 God and Natural Disasters. https://www.facebook.com/notes/ methodist-church-in-fiji-and-rotuma/god-and-natural-disasters/ I02244950II7832I/ [accessed 20 Jan 20I7]

Bishop, Julie

2013 The New Aid Paradigm. Available from the Australian Minister for Foreign Affairs website: http://foreignminister.gov.au/speeches/Pages/ 20I4/jb_sp_I 406 I 8.aspx?w=tb I CaGpkPX\% 2FlSoK\% 2Bg9ZKEg $\%_{3} \mathrm{D} \%{ }_{3} \mathrm{D}$ [accessed I 5 May 20I7]

Brennan, Imogen

20I7 Australians Sending "Unhelpful” Donations like High Heels, Handbags, Chainsaws to Disaster Zones. ABC News, Australia, I6 Jan. http://www.abc.net.au/news/20I7-OI-I 6/australians-asked-to-stop -sending-unhelpful-donations/8 I 84600 [accessed I 5 May 20I7]

Brison, Karen J

2007 The Empire Strikes Back: Pentecostalism in Fiji. Ethnology 46 (I): 2 I-39.

Carter, George

2016 Establishing a Pacific Voice in the Climate Change Negotiations. In The New Pacific Diplomacy, edited by Greg Fry and Sandra Tarte, 205-220. Acton, ACT: ANU Press.

Chester, David K and Angus M Duncan

20I0 Responding to Disasters within the Christian Tradition, with Reference to Volcanic Eruptions and Earthquakes. Religion 40 (2): 85-95.

Connell, John

2016 Fiji: Reflections in the Infinity Pool. In Touring Pacific Cultures, edited by Kalissa Alexeyeff and John Taylor, 427-438. Acton, Аст: ANU Press

Cox, John

2015 Israeli Technicians and the Post-Colonial Racial Triangle in Papua New Guinea. Oceania 85 (3):342-358. 
Cox, John, and Martha Macintyre

2014 Christian Marriage, Money Scams, and Melanesian Social Imaginaries. Oceania 84 (2): I $38-\mathrm{I} 57$.

D, Rob

2016 Facebook post: commentary over video from YouTube. Killer Cyclone Winston Is Manmade, Geoengineering Kills 22/2/16. 22 Feb. https://www.youtube.com/watch? v=flzwQoS 7 PKc [accessed $20 \mathrm{Jan}$ 20I7]

Deckard, Sharae

20 Iо Paradise Discourse, Imperialism, and Globalization: Exploiting Eden. New York: Routledge.

DFAT, Australian Department of Foreign Affairs and Trade

20I7 Tropical Cyclone Winston. http://dfat.gov.au/aid/topics/investment -priorities/building-resilience/humanitarian-preparedness-and

Dunne, Carey -response/tc-winston/Pages/default.aspx [accessed 26 May 20I7]

2017 My Month with Chemtrails Conspiracy Theorists. The Guardian, 22 May. https://www.theguardian.com/environment/2017/may/22/ california-conspiracy-theorist-farmers-chemtrails [accessed 26 May 20I7]

Eräsaari, Matti

2017 "Wasting Time" the Veratan Way: Conspicuous Leisure and the Value of Waiting in Fiji. Hau: Journal of Ethnographic Theory 7 (2):

Farbotko, Carol 309-329.

20I0 Wishful Sinking: Disappearing Islands, Climate Refugees and Cosmopolitan Experimentation. Asia Pacific Viewpoint 5I (I): 47-60.

Fountain, Phillip M, Sara Louise Kindon, and Warwick E Murray

2004 Christianity, Calamity and Culture: The Involvement of Christian Churches in the 1998 Aitape Tsunami Disaster Relief. The Contemporary Pacific I 6 (2): 32 I-355.

Fountain, Phillip, and Levi McLaughlin

2016 Salvage and Salvation: Guest Editors' Introduction. Asian Ethnology 75 (I): I-28.

Fry, Greg, and Sandra Tarte, editors 2016 The New Pacific Diplomacy. Acton, ACT: AnU Press.

Hulme, Mike 20I4 Climate Change and Virtue: An Apologetic. Humanities 3 (3): 2993 I 2.

Jolly, Margaret

2018 Horizons and Rifts in Conversations about Climate Change. In Pacific Futures: Past and Present, edited by Miranda Johnson, War- 
wick Anderson, and Barbara Brookes. Honolulu: University of Hawai'i Press, forthcoming.

Jones, Edwin

2OI 5 "Mountains of Israel": Fijians' Judaic Origins and the Use of the Old

Testament in Highland Viti Levu. Oceania 85 (3): 27 I-282.

Kabutaulaka, Tarcisius

20I5 Re-Presenting Melanesia: Ignoble Savages and Melanesian Alter-

Natives. The Contemporary Pacific 27 (I): I IO-I 45.

Kanua, Matthew, Mike Bourke, Brendan Jinks, and Mitchell Lowe

2016 Assessing Village Food Needs Following a Natural Disaster in Papua

New Guinea. Port Moresby: Church Partnership Program. https://

openresearch-repository.anu.edu.au/bitstream/I 88 5/I09282/I/

Assessing-food-needs-following-a-natural-disaster-in-Papua-New

-Guinea.pdf [accessed 26 May 2016]

Keener, Victoria W, John J Marra, Melissa L Finucane, Deanna Spooner, and

Margaret H Smith, editors

2012 Climate Change and Pacific Islands: Indicators and Impacts. Report for the 2012 Pacific Islands Regional Climate Assessment (PIRCA). Washington, DC: Island Press.

Klein, Naomi

2016 Donald Trump Isn't the End of the World, but Climate Change

May Be. Sydney Morning Herald, Io Nov. http://www.smh.com.au/ comment/donald-trump-isnt-the-end-of-the-world-but-climate -change-may-be-20 I 6 I I Io-gsm8 I 5.html [accessed I 8 Nov 20 I6]

Lata, Shalini, and Patrick Nunn

2012 Misperceptions of Climate-Change Risk as Barriers to ClimateChange Adaptation: A Case Study from the Rewa Delta, Fiji. Climatic Change I IO (I-2):I69-I 86.

Lipset, David

20I I The Tides: Masculinity and Climate Change in Coastal Papua New Guinea. Journal of the Royal Anthropological Institute I7 (I): $20-43$.

Lomborg, Bjorn

2016 About those Non-Disappearing PacificIslands. The WallStreet Journal, I3 Oct. http://www.wsj.com/articles/about-those-non-disappearing -pacific-islands-I 476400840 [accessed I 8 Nov 20I6]

Maclellan, Nic

2017 Dodging the Hard Questions in the Pacific. Lowy Interpreter, 5 Dec. https://www.lowyinstitute.org/the-interpreter/dodging-hard-questions

MacWilliam, Scott -pacific [accessed 8 Dec 20I7]

2015 Bonapartism in the South Pacific: The Bainimarama Government in 
Fiji. State, Society and Governance in Melanesia Discussion Paper

Meyer, Birgit 20 I 5/IO. Acton, АСт: The Australia National University.

2002 Pentecostalism, Prosperity and Popular Cinema in Ghana. Culture and Religion 3 (I): 67-87.

Morgain, Rachel

2015 "Break Down These Walls": Space, Relations, and Hierarchy in Fijian Evangelical Christianity. Oceania 85 (I): IO5-I I8.

Morgan, Wesley

2017 Coal Comfort: Pacific Islands on Collision Course with Australia over Emissions. The Conversation, 28 Feb. http://theconversation.com/ coal-comfort-pacific-islands-on-collision-course-with-australia-over -emissions-73662 [accessed 3 I March 20I7]

Mortreux, Colette, and Jon Barnett

2009 Climate Change, Migration and Adaptation in Funafuti, Tuvalu. Global Environmental Change I9 (I): I05-I I2.

NaDraki Weather

2016 Facebook post, 24 Feb. https://www.facebook.com/NaDrakiFiji/ posts/IO4245623582652I [accessed 3I March 2OI7]

Newland, Lynda

2004 Turning the Spirits into Witchcraft: Pentecostalism in Fijian Villages. Oceania 75 (I): I-I8.

2006 Fiji. In Globalization and the Re-Shaping of Christianity in the Pacific Islands, edited by Manfred Ernst, 3 I7-389. Suva: The Pacific Theological College.

20 I 5 The Lost Tribes of Israel—and the Genesis of Christianity in Fiji: Missionary Nations of Fijian Origin from I 835 to Cession and Beyond. Oceania 85 (3): 256-270.

20I6 From the Land to the Sea: Christianity, Community and State in Fiji-and the 20I 4 Elections. In The People Have Spoken: The 2014 Elections in Fiji, edited by Steven Ratuva and Stephanie Lawson, I09-I33. Acton, АCT: ANU Press.

Pacific Climate Change Science Program

20I I Current and Future Climate of the Fiji Islands. http://www.pacific climatechangescience.org/wp-content/uploads/20I3/06/I_PCCSP _Fiji_8pp.pdf [accessed 27 May 20I7]

Presterudstuen, Geir Henning

2016 The Value of the Vanua: The Nexus of People and Land in Fiji's Market Economy. In Anthropologies of Value: Cultures of Accumulation across the Global North and South, edited by Luis AngostoFerrández and Geir Henning Presterudstuen, 93-I I I. London: Pluto Press. 
Radio New Zealand International

2016 Fiji Pleas for a Trump Change of Heart on Climate Change. I6 Nov. http://www.radionz.co.nz/international/pacific-news/3 I 82 Io/fiji -pleas-for-a-trump-change-of-heart-on-climate-change [accessed I 8 Nov 2016]

Robbins, Joel

2004a Becoming Sinners: Christianity and Moral Torment in a Papua New Guinea Society. Berkeley: University of California Press.

2004b The Globalization of Pentecostal and Charismatic Christianity. Annual Review of Anthropology 33:I I7-I43.

2010 Anthropology, Pentecostalism, and the New Paul: Conversion, Event, and Social Transformation. South Atlantic Quarterly I09 (4): $633-652$.

Rudiak-Gould, Peter

20I4 Climate Change and Accusation: Global Warming and Local Blame in a Small Island State. Current Anthropology 55 (4): 365-386.

Ryle, Jacqueline

20I0 My God, My Land: Interwoven Paths of Christianity and Tradition in Fiji. Farnham, uK: Ashgate.

Simmons, Matilda

2016 Fiji Suffering from Kava Shortage. Pacific Islands Report, I3 June. http://www.pireport.org/articles/20 I6/06/I 3/fiji-suffering-kava -shortage [accessed 20 Jan 20I7]

Sodelpa, Social Democratic Liberal Party

2014 Reclaiming Fiji: The Manifesto of sodelpa. I3 October.

SDL, Soqosoqo Duavata Ni Lewenivanua.

2OI2 Submission to the Constitution Commission. I3 October. Suva: SDL. http://www.fijileaks.com/uploads/I/3/7/5/I3759434/new_corrected _complete_final_sdl_submission.pdf [accessed 20 Jan 20I7]

Taylor, John, and Kalissa Alexeyeff

2016 Departures and Arrivals in Touring Pacific Cultures. In Touring Pacific Cultures, edited by Kalissa Alexeyeff and John Taylor, I-28. Acton, ACT: ANU Press.

Titifanue, Jason, Romitesh Kant, Glen Finau, and Jope Tarai

20I7 Climate Change Advocacy in the Pacific: The Role of Information and Communication Technologies. Pacific Journalism Review 23 (I): I33-I 49 .

Tomlinson, Matt

2002 In God's Image: The Metaculture of Fijian Christianity. Berkeley: University of California Press.

20I I The True Me: Individualism and Biblical Types in Fijian Methodism. In Managing Modernity in the Western Pacific, edited by Mary 
Patterson and Martha Macintyre, I47-I7I. St Lucia, QLD: University of Queensland Press.

2013 The Generation of the Now: Denominational Politics in Fijian Christianity. In Christian Politics in Oceania, edited by Matt Tomlinson and Debra McDougall, 78-I02. New York: Berghahn Books.

Trompf, G W

I994 Payback: The Logic of Retribution in Melanesian Religions. Cambridge, uk: Cambridge University Press.

United Nations Office for the Coordinator of Humanitarian Affairs

2016 Fiji: Tropical Cyclone Winston - Response \& Flash Appeal - Final Summary, I 3 June.https://reliefweb.int/report/fiji/fiji-tropical-cyclone -winston-response-flash-appeal-final-summary-I 3-june-20 I 6 [accessed I3 Mar 2018]

Varandani, Suman

2016 Cyclone Winston: Fiji's Estimated Cost of Damages Exceeds \$470M, I०\% of the Island Nation's Total GDP. International Business Times, 8 March. http://www.ibtimes.com/cyclone-winston-fijis-estimated -cost-damages-exceeds-470m-Io-island-nations-total-gdp-2332 I $5 \mathrm{I}$ [accessed 5 Dec 20I6]

Waqa, Jeremiah

20 I 5 Fiji Will Pass Thru the Fire. The Rock The Kingdom of God website, 3 I May. http://www.therock.global/single-post/2O I 5/05/3 I/FIJI -WILL-PASS-THRU-THE-FIRE [accessed 26 May 20I7]

2016 God's Perfect Will for Fiji. I4 May. https://www.therock.global/ single-post/20 I 6/05/I 5/GODS-PERFECT-WILL-FOR-FIJI [accessed I6 May 20I7]

2017 Time Is Up-Fiji First! 25 Feb. https://www.therock.global/single -post/2017/02/26/TIME-IS-UP-FIJI-FIRST [accessed 26 May 20I7]

West, Harry G, and Todd Sanders, editors

2003 Transparency and Conspiracy: Ethnographies of Suspicion in the New World Order. Durham, NC: Duke University Press.

\section{Abstract}

Paradise in the Pacific is often rendered as a natural state where "native" people live in simple harmony without the need for government or state institutions. However, Christian traditions also include paradise not simply as a state of innocence but also as a narrative of salvation history in which paradise is lost through original sin and must be restored through sacrifice and repentance. This article 
takes recent Fijian Christian interpretations of Tropical Cyclone Winston as a key site in which contested ideologies of Paradise are being reworked. As the idyll of island harmony is disrupted by disaster, Christians have seen Winston as an act of divine judgment and punishment on a sinful people. This essay analyzes how narratives of a sinful nation intersect with contemporary formulations of climate change, disaster, politics, and human agency.

KEYWORDS: climate change, Christianity, natural disasters, Fiji, paradise 